\title{
КРЕДИТНО-МОДУЛЬНА СИСТЕМА У КОНТЕКСТІ РЕФОРМУВАННЯ АНГЛОМОВНОГО НАВЧАННЯ ІНОЗЕМНИХ СТУДЕНТІВ НА ДОДИПЛОМНОМУ ЕТАПІ У ЛЬВІВСЬКОМУ НАЦІОНАЛЬНОМУ МЕДИЧНОМУ УНІВЕРСИТЕТІ іМ. ДАНИЛА ГАЛИЦЬКОГО
}

\author{
Б. С. Зіменковський, М. Р. Гжегоцький, С. С. Варивода, М. І. Серветник, \\ Н. Л. Чухрай, I. І. Солонинко \\ Львівський національний медичний університет ім. Данила Галиџького
}

\section{CREDIT-MODULAR SYSTEM IN THE CONTEXT OF THE REFORM OF ENGLISH TEACHING FOREIGN STUDENTS AT UNDERGRADUATE STAGE AT LVIV NATIONAL MEDICAL UNIVERSITY BY DANYLO HALYTSKY}

\author{
B. S. Zimenkovsky, M. R. Hzhehotsky, Ye. S. Varyvoda, M. I. Servetnyk, \\ N. L. Chukhray, I. I. Solonynko \\ Lviv National Medical University by Danylo Halytsky
}

\begin{abstract}
У статті висвітлено особливості реформування англомовного навчання іноземних студентів на додипломному етапі у Львівському національному медичному університеті ім. Д. Галицького за кредитно-модульною системою.

The article highlights the features of reforming English teaching foreign students at undergraduate stage in Lviv National Medical University by Danylo Halytsky according to credit-modular system.
\end{abstract}

Вступ. У процесі об'єднання Свропи, який супроводжується формуванням спільного освітнього простору $з$ єдиними вимогами, критеріями і стандартами, важливою метою є консолідація зусиль освітянської та наукової громадськості задля забезпечення належних умов підготовки професійних кадрів світового рівня. Цей інтеграційний процес, що сформувався під егідою Болонської декларації, спрямований на впровадження загальноєвропейських норм в освіті і науці та поширення національних культурних і науково-технічних надбань серед європейських країн. Кредитно-модульна система в контексті Болонського процесу на сьогодні і надалі залишається актуальним питанням реформування вищої медичної освіти в Україні. Схема навчання за положеннями Болонської декларації $\epsilon$ не просто стратегією вибору, але і можливістю, що дозволяє нинішньому і майбутнім поколінням молодих людей, громадян України та чужоземних держав, отримати вищу освіту на рівні європейських та світових стандартів, які практично вже сформувалися і мають переваги перед нашою системою

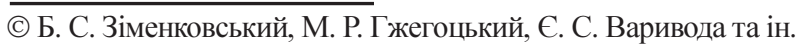

підготовки фахівців. Реформування системи вищої медичної освіти пройшло суттєвий шлях у пошуках адекватної моделі організації навчального процесу та вдосконалення системи підсумкової атестації якості підготовки випускників-іноземних громадян. 3 огляду на вищезазначені положення проблема якісного навчання іноземних студентів у вищих медичних закладах України набуває дедалі більшої актуальності та зростаючого значення, що пов'язано, насамперед, із високоякісною підготовкою фахівців, фундаментальністю знань, отриманих у ході навчання, та доступністю вищої освіти у нашій державі. Саме ці чинники спонукають іноземних громадян до навчання у медичних академіях та університетах.

Основна частина. У Львівському національному медичному університеті ім. Данила Галицького (ЛНМУ) станом на 2013-2014 навчальний рік навчаються 1002 студенти-іноземні громадяни, які презентують 44 країни світу. Англомовне відділення у ЛНМУ було започатковане у 1997 році. Впродовж 16 років гармонійно та динамічно розвивається форма навчання іноземців англійською мовою, постійно зростає кількість аплікантів та студентів англомов- 
ного відділення. Про це яскраво свідчать показники числа зарахованих на навчання англійською мовою. Якщо на момент започаткування англомовного відділення у 1997 році кількість студентів медичного, стоматологічного та фармацевтичного факультетів тоді Львівського державного медичного університету ім. Данила Галицького складала 20 осіб, у 2003 році (рік першого випуску студентів медичного факультету) це число складало 147 студентів, то на поточний момент ця кількість зросла порівняно з 1997 роком майже у 35 разів і складає 706 осіб, порівняно з 2003 роком - у 4,8 раза. Нині загальне число студентів англомовного відділення становить 706 осіб, 3 них студентів медичного факультету - 494, стоматологічного факультету - 160, фармацевтичного факультету - 52. Англійською мовою навчання охоплено шість курсів медичного і п’ять курсів стоматологічного та фармацевтичного факультетів. Наявність такого широкого спектра спеціальностей, з одного боку, дає можливість викладачам, які займаються зі студентами англомовного відділення, постійно вдосконалювати свої фахові знання, з іншого - це серйозне джерело надходжень коштів до бюджету університету, загальна сума яких вже зараз складає більше ніж 2 млн доларів.

Відповідно до наказу МОЗ України № 148 “Про заходи щодо реалізації положень Болонської декларації в системі вищої медичної та фармацевтичної освіти” у ЛНМУ у 2004 році розпочато реформування навчального процесу за кредитно-модульною системою, яке триває і зараз. На поточний момент кредитно-модульна система навчання впроваджена на усіх курсах медичного факультету, стоматологічного та фармацевтичного факультетів. Створено нові навчальні плани у кредитах ECTS, структуровано програми 3 навчальних дисциплін на підсумкові та змістові модулі, розроблено методичні рекомендації з відповідних дисциплін, вивчення клінічних дисциплін проводиться шляхом ротації циклів відповідних предметів або їх модулів 3 обов' язковим впровадженням принципів доказової медицини. Розроблено та затверджено положення про навчання іноземних студентів англійською мовою, яке грунтується на безумовному дотриманні всіх нормативних документів МOH та МO3 України, Міністерства закордонних справ України, щодо правил запрошення, прийому, реєстрації та навчання іноземних громадян. Позитивним моментом слід вважати і те, що всі навчальні програми для англомовних студентів повністю приведені у відповідність до вимог і не відрізняються від базових програм, за якими навчаються українські студенти. Відповідно до базових програм та навчальних планів, з метою забезпечення лекцій та практичних занять необхідною документацією викладачами університету проведено та надалі проводиться великий обсяг роботи по створенню методичних посібників із різноманітних дисциплін. Англомовні студенти медичного, стоматологічного та фармацевтичного факультетів навчаються за кредитно-модульною системою, що дозволить в майбутньому максимально наблизити рівень їх фахової підготовки до рівня підготовки спеціалістів у Свропі. Оскільки студенти англомовного відділення навчаються за базовими програмами, ухваленими Міністерством охорони здоров'я України, необхідною складовою їх навчання $\epsilon$ участь у ліцензованих інтегрованих іспитах “КРОК1" та "КРОК-2". Вищезазначені іспити складають англомовні студенти медичного, стоматологічного та фармацевтичного факультетів, що дає змогу студентам поглиблювати та закріплювати теоретичні знання з відповідних базисних та клінічних дисциплін.

Висновок. Планомірний розвиток англомовної форми навчання студентів-іноземних громадян згідно 3 положеннями Болонської системи - це не тільки великий обсяг надходжень до бюджету університету, але й грунтовний базис для серйозного вдосконалення та підвищення фахового рівня викладачів, можливість широкої та глибокої інтеграції наукових співпрацівників університету до європейської наукової спільноти. 